\begin{tabular}{|l|c|c|c|r|}
\hline $\begin{array}{l}\text { Cuadernos de Investigación Geográfica } \\
\text { Geographical Research Letters }\end{array}$ & 2017 & No $^{\circ} 43(2)$ & pp. 429-448 & $\begin{array}{r}\text { ISSN 0211-6820 } \\
\text { eISSN 1697-9540 }\end{array}$ \\
\hline
\end{tabular}

DOI: http://doi.org/10.18172/cig.3229

(C) Universidad de La Rioja

\title{
THE LAST DEGLACIATION OF ALASKA
}

\author{
J.P. BRINER ${ }^{1 *}$, J.P. TULENKO ${ }^{1}$, D.S. KAUFMAN ${ }^{2}$, \\ N.E. YOUNG ${ }^{3}$, J.F. BAICHTAL ${ }^{4}$, A. LESNEK ${ }^{1}$ \\ ${ }^{1}$ Department of Geology, University at Buffalo, Buffalo, New York, USA. \\ ${ }^{2}$ School of Earth Sciences and Environmental Sustainability, \\ Northern Arizona University, Flagstaff, Arizona 86011, USA. \\ ${ }^{3}$ Lamont-Doherty Earth Observatory, Columbia University, Palisades, New York, USA. \\ ${ }^{4}$ Tongass National Forest, Thorne Bay, Alaska, USA.
}

\begin{abstract}
We review available chronologies that constrain the timing of glacier fluctuations during the last deglaciation in Alaska. We address three questions relating to the last glacial termination: (i) How did the timing of glacier recession relate to buildup of global $\mathrm{CO}_{2}$, such as during the onset of $\mathrm{CO}_{2}$ rise at $\sim 18 \mathrm{ka}$ ? (ii) Did glaciers fluctuate in synchrony with Heinrich Stadial 1 (18-14.6 ka)? And, (iii) what is the spatio-temporal pattern of glacier change during the climatically turbulent late glacial interval (14.6-11.7 ka)? The existing record is incomplete, yet reveals that most Alaskan glaciers experienced significant retreat ( $40 \%$ of their Last Glacial Maximum lengths) prior to the onset of $\mathrm{CO}_{2}$ rise $\sim 18 \mathrm{ka}$. This points to stronger insolation forcing of Alaskan glaciers compared to mid-latitude glaciers. Despite some glacier re-advances and standstills during Heinrich Stadial 1, most glaciers continued to recede. This suggests that glaciers in Alaska were relatively immune to the far-field effects of Atlantic meridional overturning circulation. Finally, the majority of glaciers ( 9 out of 14 available records) were up-valley of their late Holocene glacier extents during the Younger Dryas. Most of the sites with evidence for relatively extensive glaciers during the Younger Dryas are in southern Alaska, which may relate to moisture changes associated with the flooding of Bering Strait as much as it does to changes in North Atlantic Ocean circulation.
\end{abstract}

\section{La última deglaciación de Alaska}

RESUMEN. Revisamos las cronologías disponibles que identifican la temporalidad de las fluctuaciones glaciares durante la última deglaciación en Alaska. Nos centramos en tres cuestiones relacionadas con el final de la última glaciación: (i) ¿Cómo se relaciona el momento de la recesión glaciar con el aumento global de $\mathrm{CO}_{2}$ hacia $\sim 18 \mathrm{ka}$ ? (ii) ¿Fluctuaron los glaciares en sincronía con el Stadial 1 de Heinrich (18-14.6 ka)? Y (iii) ¿Cuál es el patrón espacio-temporal del cambio glaciar durante el último intervalo glaciar climáticamente turbulento (14.6-11.7 $\mathrm{ka})$ ? El registro existente es incompleto y revela que la mayoría de los glaciares de 
Alaska experimentaron un retroceso significativo ( 40\% de su longitud durante el Último Máximo Glaciar) anterior al inicio de aumento de $\mathrm{CO}_{2}$ hacia $18 \mathrm{ka}$. Esto apunta a una mayor insolación en los glaciares de Alaska en comparación con los glaciares de las latitudes medias. A pesar de algunos reavances glaciares durante el Stadial 1 de Heinrich, la mayoría de los glaciares continuaron retrocediendo. Esto sugiere que los glaciares de Alaska fueron relativamente inmunes a los efectos de la circulación meridional atlántica de retorno. Finalmente, durante el Younger Dryas la mayoría de los glaciares (9 de 14 registros) estaban por encima de su posición de finales del Holoceno. La mayoría de los lugares con evidencia de glaciares relativamente extensos durante el Younger Dryas están en el sur de Alaska, lo que puede relacionarse con cambios de humedad asociados a la inundación del estrecho de Bering tanto como a los cambios en la circulación del Atlántico Norte.

Keywords: Alaska, deglaciation, glacier, geochronology, paleoclimate.

Palabras clave: Alaska, deglaciación, glaciar, geocronología, paleoclima.

Received: 31 January 2016 Accepted: 4 April 2017

* Corresponding author: Jason P. Briner, Department of Geology, University at Buffalo, Buffalo, New York, USA. E-mail address: jbriner@buffalo.edu

\section{Introduction}

Facing a major episode of global deglaciation today (Roe et al., 2017), lessons learned from the last deglaciation are relevant for enriching our understanding of glacier sensitivity to climate forcing. The last deglaciation refers to the transition from glacial maximum conditions between 26 and $19 \mathrm{ka}$ (Clark et al., 2009) to the Holocene interglaciation period (the past 11,700 years). Detailed reconstructions of mountain glacier change from the last deglaciation exist from around the globe (e.g., Shakun et al., 2015), although complete, high-resolution records of glacier fluctuations through the last deglaciation from single valleys remain sparse (e.g., Putnam et al., 2010, 2013). Alaska fills an important spatial gap in the available records of mountain glacier change during the last deglaciation. Unlike elsewhere across the high northern latitudes, which was mostly smothered by continental ice sheets during glacial maxima, Alaska remained only partially glaciated (Fig. 1). Thus, Alaska is one of few high latitude regions with detailed geomorphic records of mountain glacier extent during the last deglaciation.

Presently several outstanding questions about glacier behavior during the last deglaciation remain unresolved. For example, how did the timing of glacier recession relate to buildup of global $\mathrm{CO}_{2}$, such as during the onset of $\mathrm{CO}_{2}$ rise at $\sim 18 \mathrm{ka}$ ? What was the expression of glacier change during Heinrich Stadial 1 ( $\sim 18-14.6 \mathrm{ka})$ ? Finally, what is the spatio-temporal record of glacier change during the climatically turbulent 
late glacial interval, such as during the Bølling-Allerød (14.6-12.9 ka), Antarctic Cold Reversal ( 14-13 ka), and Younger Dryas (12.9-11.7 ka) periods? These three questions can be addressed with high-resolution and precise glacial chronologies from around the globe spanning the last deglaciation. Embedded within these questions is the role of polar amplification, an underlying feature of the climate system that may influence highlatitude glacier change differently than elsewhere. However, there are currently very few complete mountain glacier chronologies from the high northern latitudes. Despite some chronological constraints of mountain glacier fluctuations from Alaska, they are still mostly scattered data points from different mountain ranges around the state. Nevertheless, adequate information is available from a few places to begin to address the above questions.

This paper summarizes some key records of glacier change in Alaska spanning the last deglaciation. We build from the most recent review of the Pleistocene glacier history of Alaska (Kaufman et al., 2011). There have been some new glacial chronology studies published since that time, and furthermore, unlike past reviews spanning the Late Pleistocene (Briner and Kaufman, 2008; Kaufman et al., 2011) and spanning the Holocene (Barclay et al., 2009; Kaufman et al., 2016), this paper focuses solely on the last deglaciation. This is the first review paper on the glaciation history of Alaska to do so. Our goal is not to provide an exhaustive review of all publications on glacier history in Alaska during this interval, but rather to focus on select records that are most useful for addressing outstanding questions about the last glacial termination in the state.

\section{Key glacial chronologies}

To address the three questions outlined in the introduction, we seek the best available continuous glacial histories from single mountain ranges, or more ideally, highresolution chronologies from single glacier systems. Glacier chronologies that most closely meet this goal exist in the Brooks Range, Alaska Range, Ahklun Mountains and southern Alaska (Fig. 1), and these records have allowed us to build glacier histories spanning the last deglaciation in these select areas. Below, we review some of the key records from these locations and summarize the glacier history from each. All cosmogenic ${ }^{10} \mathrm{Be}$ exposure ages reported in this paper have been calculated using the same parameters: the Arctic ${ }^{10} \mathrm{Be}$ production rate of Young et al. (2013) using version 3.0 of the calculator from Balco et al. (2008; http://hess.ess.washington.edu) with Lm scaling (see Balco et al., 2008). Table 1 shows all samples discussed here, and includes ages calculated using alternative production rates and scaling schemes. A Google Earth KMZ supplemental file shows the location all of the samples discussed here, and when coupled with the Arctic DEM KMZ file (https:/elevation2.arcgis.com/arcgis/rest/ services/Polar/ArcticDEM/ImageServer), one can see the all ages discussed and their geomorphic context. All ${ }^{14} \mathrm{C}$ ages reported here (Table 2) are in calendar years BP and re-calculated using Calib 7.1 (Stuiver et al., 2017; http://calib.org/calib). All marine samples have been calibrated using the standard marine reservoir correction; there is no overwhelming information available from southern Alaska that suggests otherwise (Reger et al., 2008a; Kopczynski et al., 2017). 
Table 1. Cosmogenic nuclide exposure ages discussed in text.

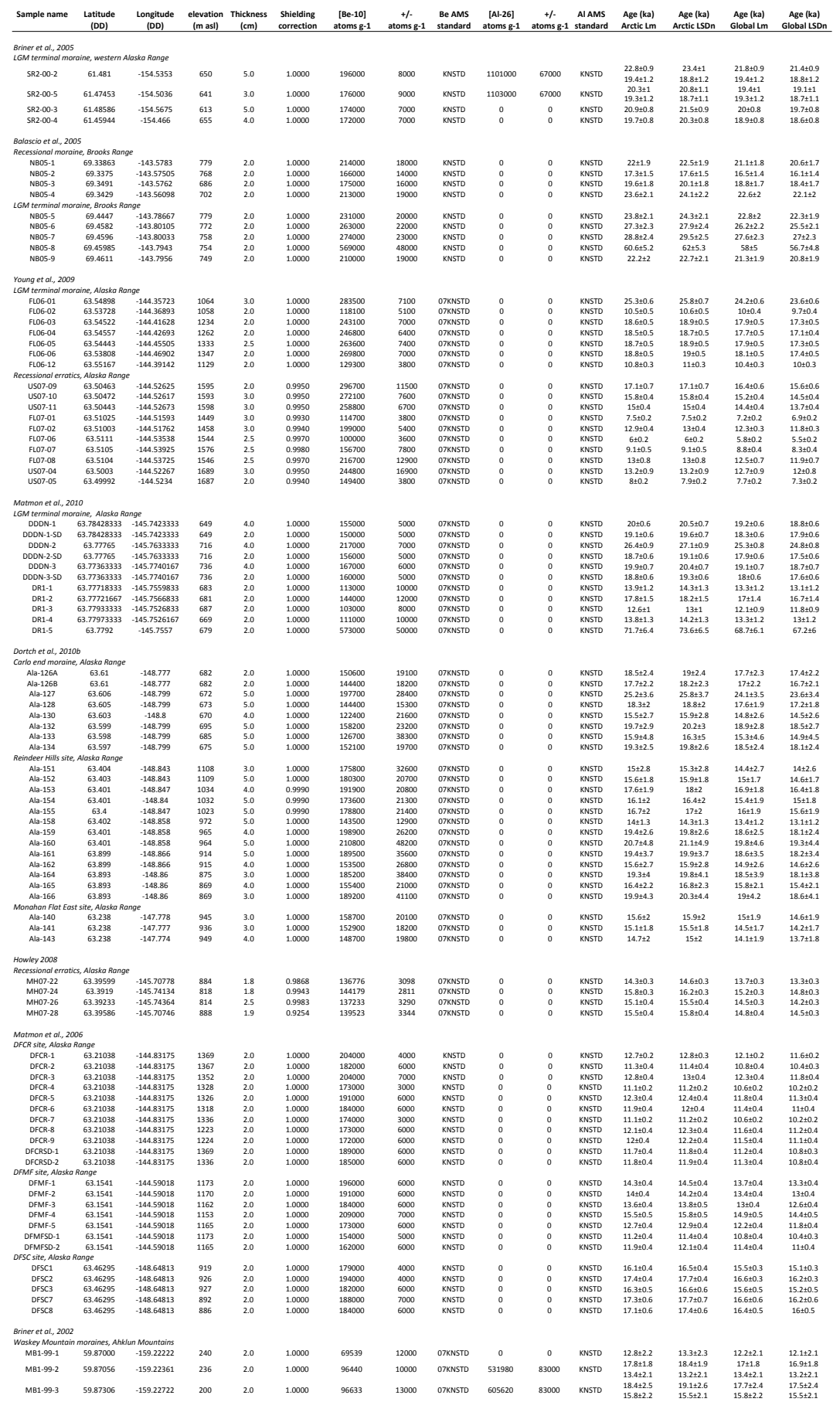




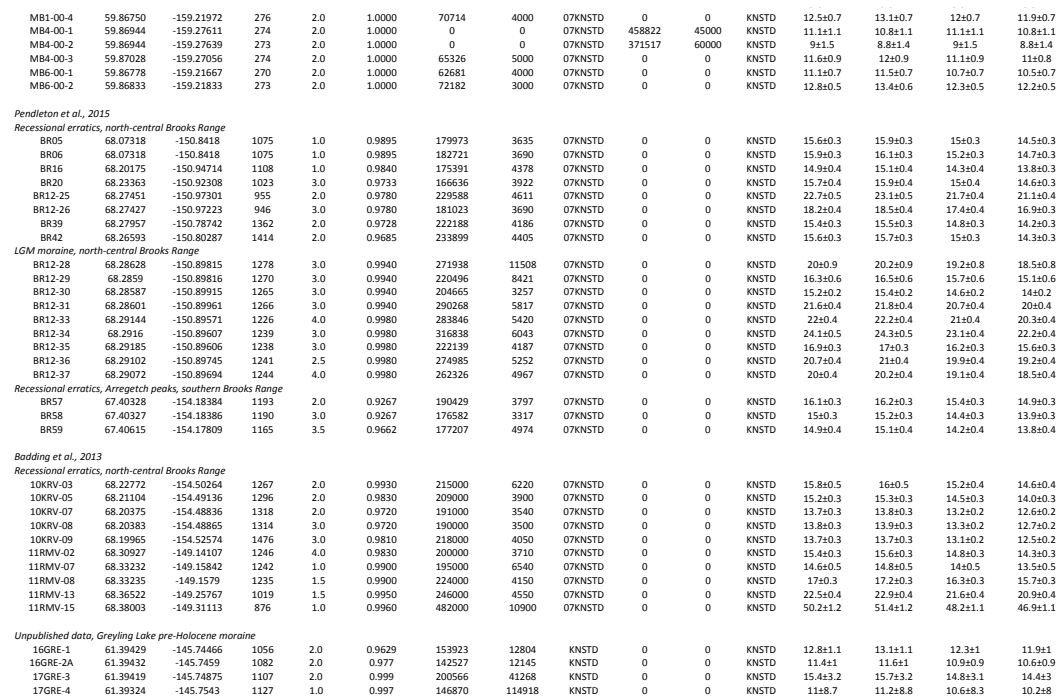

Notes: sample density is $2.65 \mathrm{~g} / \mathrm{cc}$ for all samples; ages are caculated with no surface erosion, and no snow cover. For samples with both ${ }^{10} \mathrm{Be}$ and ${ }^{26} \mathrm{Al}$ ages, ${ }^{10} \mathrm{Be}$ ages are listed in the top row, ${ }^{26} \mathrm{Al}$ ages are listed in the bottom row.

Table 2. Radiocarbon ages used for time-distance diagrams reported on Figure 2.

\begin{tabular}{ccccll}
\hline Lab ID & 14C age & 2 sigma range & $\begin{array}{c}\text { 2 sigma } \\
\text { mid-point }\end{array}$ & location & \multicolumn{1}{c}{ source } \\
\hline Ahklun Mountains & & & & & \\
\hline AA-23082 & $16,890 \pm 120$ & $20,050-20,670$ & $20,360 \pm 310$ & $\begin{array}{l}\text { Goodnews River } \\
\text { valley }\end{array}$ & Manley et al. (2001) \\
NSRL-11058 & $9710 \pm 90$ & $10,760-11,250$ & $11,010 \pm 250$ & Waskey Lake & Levy et al. (2004) \\
\hline Alaska Range, McKinley River sequence & & & \\
\hline USGS-656 & $19,700 \pm 200$ & $23172-24195$ & $23,680 \pm 510$ & MP1 maximum age & Ten Brink and Waythomas (1985) \\
I-11228 & $17,800 \pm 290$ & $20794-22288$ & $21,540 \pm 750$ & MP1 minimum age & Ten Brink and Waythomas (1985) \\
Not available & $17,150 \pm 150$ & $20276-21098$ & $20,690 \pm 410$ & MP2 maximum age & Werner et al. (1993) \\
CAMS-11704 & $14,110 \pm 150$ & $16658-17576$ & $17,120 \pm 460$ & MP2 minimum age & Child (1995) \\
CAMS-15638 & $12,780 \pm 170$ & $14448-15793$ & $15,120 \pm 670$ & MP3 maximum age & Child (1995) \\
GX-6284 & $12,340 \pm 205$ & $14050-15130$ & $14,560 \pm 540$ & MP3 minimum age & Ten Brink and Waythomas (1985) \\
I-10536 & $10,370 \pm 150$ & $11629-12144$ & $12,140 \pm 520$ & MP4 maximum age & Ten Brink and Waythomas (1985) \\
I-10535 & $9860 \pm 140$ & $11147-11919$ & $11,530 \pm 390$ & MP4 minimum age & Ten Brink and Waythomas (1985) \\
\hline
\end{tabular}

\subsection{Brooks Range}

Glacial geomorphic features formed during the Last Glacial Maximum (LGM, locally termed the Itkillik II glaciation) are widespread in the Brooks Range (e.g., Hamilton et al., 1986; Hamilton, 2003). These deposits have been used to generate a relatively complete 
outline of LGM glacier extent (Fig. 1; Kaufman et al., 2011). The age of LGM moraines are constrained loosely with radiocarbon dating in downvalley outwash sequences to 27-25 cal ka and shortly following 23 cal ka (Hamilton et al., 1986). LGM terminal moraines have been dated directly with cosmogenic ${ }^{10} \mathrm{Be}$ exposure dating in two locations: $25.6 \pm 3.1 \mathrm{ka}$ $(\mathrm{n}=4$, excluding one outlier) in the northeastern portion of the range (Balascio et al., 2005), and $21.0 \pm 0.8 \mathrm{ka}$ ( $\mathrm{n}=5$, excluding 4 outliers) in the north-central Brooks Range (Pendleton et al., 2015). Despite a high degree of scatter in both ${ }^{10} \mathrm{Be}$ chronologies, the two ages are markedly different. The geologic and analytical sources of scatter in cosmogenic nuclide exposure dating are described by Balco (2011) and Heyman et al. (2011). It is possible that the two-fold terminal moraine sequence that Hamilton (1986) described is expressed differently in different parts of the Brooks Range. For example, perhaps the older LGM advance is the outermost in the northeastern Brooks Range, and the younger LGM advance is the outermost in the north-central Brooks Range. Alternatively, the moraine boulders might have been influenced by isotopic inheritance and/or exhumation, yielding scatter or perhaps a systematic offset from their true age.

A number of moraines situated between extant glacier termini and LGM moraines are present throughout the Brooks Range, but these moraines have been directly dated in only two valleys. In the northeastern Brooks Range, Balascio et al. (2005) dated a moraine downvalley of the Hubley Glacier to $20.7 \pm 2.8 \mathrm{ka}(\mathrm{n}=4)$. In the north-central Brooks Range, Pendleton et al. (2015) dated a moraine to $17.2 \pm 1.0 \mathrm{ka}$ ( $\mathrm{n}=4$, excluding one outlier). In both locations, these moraine ages are consistent with their respective terminal moraine ages. It is possible that the Hubley Glacier moraine is equivalent to the terminal moraine dated by Pendleton et al. (2015), and together with the LGM terminal moraine dated by Balascio et al. (2005) represents the two-fold LGM moraine sequence described by Hamilton (1986).

In terms of the subsequent deglaciation, even less is known. Hamilton (2003) interpreted alluviation near the north-central Brooks Range front as a glacier advance between $\sim 15$ and $\sim 13$ cal ka. However, subsequent ${ }^{10} \mathrm{Be}$ dating of upper valley reaches in the same area reveal that glaciers were retreating into their cirques during this interval. Thus, the alluviation event that Hamilton (2003) dated was likely not related to a glacier advance. In fact, in three different valleys throughout the north-central Brooks Range, and one valley in the Arregetch Peaks area of the southern Brooks Range, published ${ }^{10} \mathrm{Be}$ ages on moraine boulders closest (directly adjacent in most cases) to extant glacier termini (or just beyond late Holocene moraines) average $15.0 \pm 0.8 \mathrm{ka}(\mathrm{n}=6$; Badding et al., 2013; Pendleton et al., 2015). Collectively, these chronologies indicate that glaciers in the Brooks Range retreated into their cirques near or slightly prior to the onset of the Bølling-Allerød period. These ages also reveal that all subsequent glacier fluctuations, if any, were restricted to within the footprint of late Holocene glacier fluctuations.

Taken together, we assemble a continuous glacier timeline for the central Brooks Range (excluding the northeastern Brooks Range data), where most of the existing chronology is from. We include the information above, in addition to ${ }^{10} \mathrm{Be}$ ages from erratic boulders and bedrock along the middle reaches of a glacial valley investigated by Pendleton et al. (2015). The time-distance diagram (Fig. 2) encompasses the glacial 


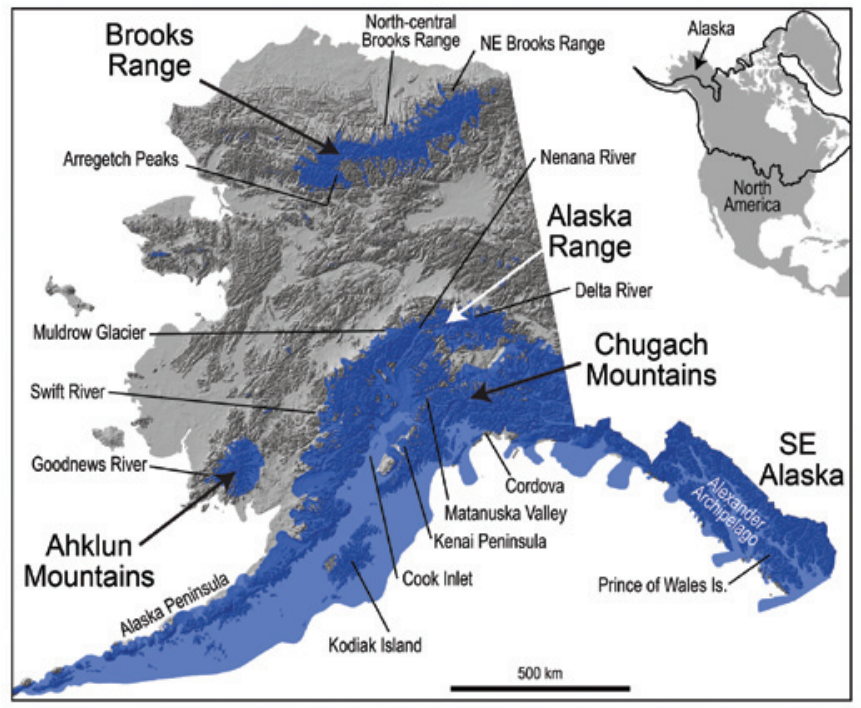

Figure 1. Map of Alaska showing extent of LGM ice in blue (Kaufman et al., 2011) and key place names mentioned in text; inset shows LGM ice sheet extent in North America (Dyke et al., 2003).

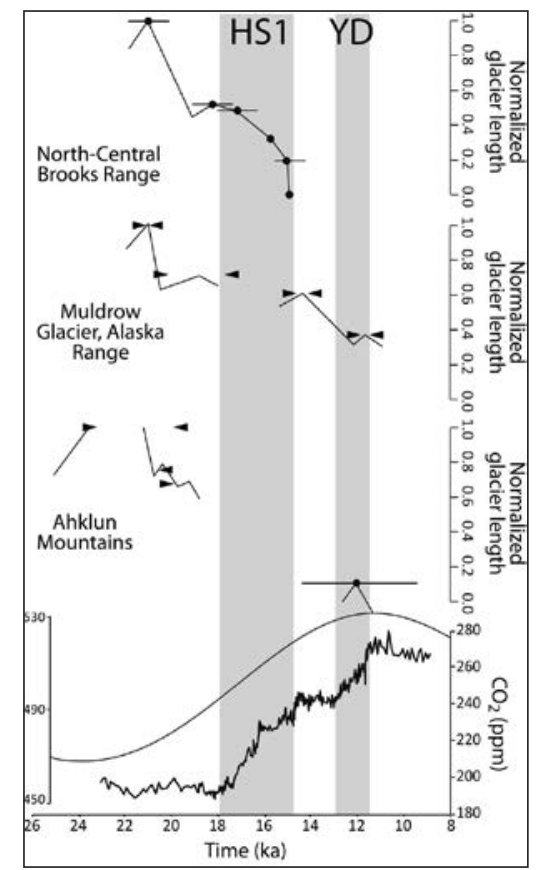

Figure 2. Glacier time-distance diagrams showing best available chronology (triangles = radiocarbon ages; right-pointing arrows = maximum age; left-pointing arrows = minimum age; circles = cosmogenic nuclide exposure ages. Sample positions are normalized using the distance between present glacier termini or paleo-ice divide and the maximum LGM ice extent. At bottom, $\mathrm{CO}_{2}$ (Marcott et al., 2014) and 61 ${ }^{\circ} \mathrm{N}$ June 21 insolation (Laskar et al., 2004) WM-2, are shown. 
history outlined above; it reveals significant retreat between $\sim 21$ and $\sim 17 \mathrm{ka}$, a glacier standstill or re-advance $\sim 17 \mathrm{ka}$, and subsequent glacier recession to within late Holocene glacier limits by $\sim 15 \mathrm{ka}$.

\subsection{Alaska Range}

The Alaska Range was heavily glaciated during the last glacial cycle. Despite being connected to the Cordilleran Ice Sheet complex, ice fields fed valley glaciers that flowed into the unglaciated terrain north and west of the Alaska Range crest (Kaufman et al., 2011). South of the divide, much more extensive glaciers converged to form broad lobes that filled lowlands and coastal areas. Moraines within and north of the Alaska Range have been dated, although generally only one or two moraines per valley, and not continuous glacier chronologies that span from LGM moraines to modern glacier termini, with the exception of Muldrow Glacier deposits in Denali National Park.

Porter et al. (1983) provide the most detailed review to date, although not the most recent (Hamilton, 1994), on existing ${ }^{14} \mathrm{C}$ ages for the timing of late Pleistocene glacier advances in the Alaska Range. Several maximum-limiting ${ }^{14} \mathrm{C}$ ages constrain the initial late Pleistocene advance to sometime after ca. 27 ka (Porter et al., 1983). In Denali National Park, the maximum late Pleistocene (McKinley Park [MP] I) moraine of the Muldrow Glacier was emplaced between $21.5 \pm 0.7$ and $20.7 \pm 0.4 \mathrm{cal} \mathrm{ka}$, based on ${ }^{14} \mathrm{C}$ ages of organic remains below and above till (Ten Brink and Waythomas, 1985; Werner et al., 1993). Based on ${ }^{14} \mathrm{C}$ dated sediment cores in and near Wonder Lake, two younger phases of ice advance occurred between $20.7 \pm 0.4$ and $17.1 \pm 0.5$ cal ka (MP II; Werner et al., 1993; Child, 1995), $15.1 \pm 0.7$ and $14.6 \pm 0.5$ cal ka (MP III; Child, 1995; Ten Brink and Waythomas, 1985). The youngest moraine (MP IV) is constrained by ${ }^{14} \mathrm{C}$ ages on the initiation of peat growth down-valley of the moraine $(12.1 \pm 0.5 \mathrm{cal} \mathrm{ka})$ and on the moraine (11.5 $\pm 0.4 \mathrm{cal} \mathrm{ka}$; Ten Brink and Waythomas, 1985). Dortch et al. (2010a) attempted to use ${ }^{10} \mathrm{Be}$ dating on the Muldrow Glacier moraines, but their results are too scattered to determine the timing of deglacial ice-marginal positions. We use the existing chronological information to construct a time-distance history of the paleo-Muldrow Glacier (Fig. 2).

Additional chronological control from elsewhere in the northern Alaska Range includes the headwaters of the Nenana River valley where Dortch et al. (2010b) dated several moraines and sets of erratic boulders, although not all sample sites yielded coherent results. At the Carlo Moraine, which they interpret to be within the LGM limit, they report an average ${ }^{10} \mathrm{Be}$ age of $17.9 \pm 1.6 \mathrm{ka}(\mathrm{n}=7$, excluding one outlier). At sites they interpret to be morpho-stratigraphically inboard of the Carlo limit, Dortch et al. (2010b) report clusters of erratics that date to $17.4 \pm 2.2 \mathrm{ka}(\mathrm{n}=13$; their Reindeer Hills site) and 15.2 $\pm 0.5 \mathrm{ka}(\mathrm{n}=3$; their Monahan Flat East site), although given that these sites are not in a single valley, it is difficult to know where they should be plotted in timedistance space. Similarly, Matmon et al. (2006) provide five ${ }^{10} \mathrm{Be}$ ages from a site (their site DFSC) near Dortch et al.'s (2010b) Reindeer Hills site that average $16.9 \pm 0.6 \mathrm{ka}$ $(n=5)$. It is not entirely clear where this site lies in relation to the LGM ice extent other than somewhere within it. Finally, Ten Brink and Waythomas (1985) reported a ${ }^{14} \mathrm{C}$ age 
from sediments beneath a recessional moraine in the Nenana River valley of $16.3 \pm 1.2$ cal ka, suggesting that at least one of the recessional moraines is from a re-advance that occurred after $\sim 16.3 \mathrm{ka}$. Taken together, the available chronology from the Nenana River catchment is insufficient to precisely determine the age of the LGM terminal moraine, although some scattered locations upvalley were ice free during the middle stages of deglaciation; one recessional moraine dates to $\sim 18 \mathrm{ka}$, and another post-dates $\sim 16.3 \mathrm{ka}$.

Farther east, Matmon et al. (2010) obtained a ${ }^{10} \mathrm{Be}$ age of $19.4 \pm 0.9 \mathrm{ka}(\mathrm{n}=6$, excluding 5 outliers) for the terminal moraine along the Delta River valley. Slightly east of the Delta River valley, Young et al. (2009) dated a terminal moraine that yielded an average ${ }^{10} \mathrm{Be}$ age of $18.7 \pm 0.2 \mathrm{ka}$ ( $\mathrm{n}=4$, excluding three outliers). Both of these ages are consistent with a minimum-limiting ${ }^{14} \mathrm{C}$ age of $\sim 17.9$ cal ka for an LGM terminal moraine in the region reported by Reger et al. (2008b). One additional site with known direct ages of the LGM terminal moraine deposited by glaciers flowing out of the Alaska Range is the Swift River valley, where Briner et al. (2005) report an average ${ }^{10} \mathrm{Be}$ age of $20.4 \pm 0.7 \mathrm{ka}(\mathrm{n}=4)$.

In terms of deglaciation to within modern glacial limits in the Alaska Range, Young et al. (2009) obtained ${ }^{10} \mathrm{Be}$ ages on erratic boulders from two additional sites in the valley east of the Delta River. Erratics from one site well upvalley from the terminal moraine yielded an average ${ }^{10} \mathrm{Be}$ age of $15.9 \pm 1.1 \mathrm{ka}(\mathrm{n}=3)$, and erratics from the other site lie just beyond late Holocene glacier deposits and yielded an average ${ }^{10} \mathrm{Be}$ age of 12.9 $\pm 0.2 \mathrm{ka}$ ( $\mathrm{n}=3$, excluding 4 outliers). Nearby, but on the south side of the divide, Matmon et al. (2006) dated moraines offset by the Denali Fault just beyond late Holocene glacier deposits at two locations. One site (their site DFCR) yielded an average ${ }^{10} \mathrm{Be}$ age of 11.9 $\pm 0.6 \mathrm{ka}(\mathrm{n}=11)$, and their other site (DFMF) yielded an average ${ }^{10} \mathrm{Be}$ age of $13.4 \pm 1.5 \mathrm{ka}$ $(n=5)$. Finally, Howley (2008) reported ${ }^{10} \mathrm{Be}$ ages from four erratic boulders just beyond late Holocene moraines in the Delta River valley, which average $15.2 \pm 0.7 \mathrm{ka}$. Taken together, these existing ages from sites near extant glaciers suggest that glaciers retreated to within their late Holocene footprints roughly during the Bølling-Allerød period, with the exception of an apparently later re-advance between $\sim 12.3$ and $\sim 11$ cal ka (MP IV; Ten Brink and Waythomas, 1985) and a moraine dated by Matmon et al. (2006) to $11.9 \pm 0.6 \mathrm{ka}$.

\subsection{Ahklun Mountains}

The Ahklun Mountains, southwestern Alaska, supported an ice cap independent of the Cordilleran Ice Sheet (Kaufman et al., 2011; Fig. 1). Firm chronological constraints on LGM deposits and subsequent deglaciation are sparse and scattered across the region, but in the southwestern Ahklun Mountains, the timing of the maximum LGM extent is reasonably well constrained. There, Kaufman et al. (2003) dated lacustrine sediments related to the LGM ice extent of a major outlet glacier that flowed down the Goodnews River valley. The LGM sediment unit, dated by a macrofossil-based ${ }^{14} \mathrm{C}$ age-depth model that was updated in Kaufman et al. (2012), spans from 23.9 to $19.4 \mathrm{cal}$ ka. Closer to the ice cap center in that same valley, a ${ }^{14} \mathrm{C}$ age from a sediment section constrains one recessional moraine to be older than $\sim 20.4 \mathrm{cal} \mathrm{ka}$, and a recessional moraine farther upvalley to be younger than $20.4 \mathrm{cal} \mathrm{ka}$ (Manley et al., 2001). 
In the high, eastern-central portion of the Ahklun Mountains, not far downvalley from present-day glaciers, a moraine sequence (the Waskey Mountain moraines) dates to the late glacial period. Moraine boulders yield an average ${ }^{10} \mathrm{Be} /{ }^{26} \mathrm{Al}$ age of $12.0 \pm 2.4 \mathrm{ka}(\mathrm{n}=9$; Briner et al., 2002). A lake that is impounded by the moraines has a basal ${ }^{14} \mathrm{C}$ age of $\sim 11.0$ cal ka, consistent with the ${ }^{10} \mathrm{Be}$ age for the Waskey Mountain moraines (Levy et al., 2004). To summarize, there seems to have been significant glacier recession early in the last deglacial period in the Ahklun Mountains, but glaciers lingered until the late glacial period (Fig. 2); the Waskey Mountain moraines may date to within the Younger Dryas period.

\subsection{Southern Alaska}

A few relevant ages scattered across southern Alaska help address this paper's key questions. Dating the LGM extent is difficult given that glaciers terminated mostly on the continental shelf (Kaufman et al., 2011). To date, the best constraints on the timing of the LGM are from Mann and Peteet (1994), who obtained several maximum and minimum ${ }^{14} \mathrm{C}$ ages from Kodiak Island (Fig. 1). Their data indicate that the LGM extent on Kodiak Island occurred between 26.9 and $17.9 \mathrm{cal} \mathrm{ka}$. Cook Inlet, which was occupied by ice during the LGM, was inundated by the sea as early as $\sim 19.4 \mathrm{cal} \mathrm{ka}$, and peat formed within the LGM ice extent mapped by Kaufman et al. (2011) as early as $\sim 18.5$ cal ka (Reger et al., 2008a). Reger et al. (2008a) outline a subsequent glacial history of the Kenai Peninsula that includes several glacial advances occurring $\sim 18.5$ to $\sim 17.5$ cal ka (Killey Stade), 17.5 to $\sim 16.0$ cal ka (Skilak Stade) and $\sim 15.0 \mathrm{ka}$ (Elmendorf Stade). The age control for these advances is relatively sparse and from widely distributed sites, and have been updated in a few places (see below).

Kopczynski et al. (2017) compiled ${ }^{14} \mathrm{C}$ ages associated with the Elmendorf Moraine in the Anchorage Lowlands and subsequent recession up the Matanuska valley, in the western Chugach Mountains. The moraine was emplaced $~ 16.5$ cal ka as bracketed by ${ }^{14} \mathrm{C}$ ages on marine material (Bootlegger Cove Formation) from below, and organicrich sediments from above. Their age assignment is slightly older than that of Reger $e t$ al.'s (2008a), who probably relied on ${ }^{14} \mathrm{C}$ ages of shells and barnacles in the Bootlegger Cove Formation that were re-worked during emplacement of the Elmendorf Moraine, the youngest of which is $15.9 \pm 1.6 \mathrm{cal} \mathrm{ka}$. A basal ${ }^{14} \mathrm{C}$ age from Hidden Lake (Ager and Sims, 1981; Kaufman, unpublished) of $\sim 15$ cal ka provides a new minimum age for the Skilak Stade, somewhat younger than Reger et al.'s (2008a) timeline for Kenai Peninsula glaciation. Taken together, these dated deposits reveal that, following the LGM advance, there were three additional moraine-forming glacial events that occurred prior to the Bølling-Allerød period. It is difficult to know how much recession occurred prior to the $\mathrm{CO}_{2}$ rise $\sim 18 \mathrm{ka}$, but mapping from Reger et al. (2008a) shows significant ice recession by $18-19$ cal ka prior to the Killey Stade.

In terms of the subsequent glacial history, not much is known from a single location, but there are a few scattered locations across southern Alaska with age control. We review these sites from west to east. On Kodiak Island, Mann and Peteet (1994) ${ }^{14} \mathrm{C}$ dated a package of glaciotectonized sediments to 13.4 to $13.1 \mathrm{cal} \mathrm{ka}$; this location is $\sim 40 \mathrm{~km}$ downvalley from the nearest glaciers. On the Kenai Peninsula, lake sediments 
from Emerald Lake, which lies across a low topographic threshold from a present-day glacier, transition from pro-glacial to non-glacial slightly before $11.2 \mathrm{cal} \mathrm{ka}$ (LaBrecque and Kaufman, 2016). Furthermore, there is a layer of pro-glacial sediments dating from $\sim 10.8$ to $\sim 9.8 \mathrm{cal} \mathrm{ka}$; the sediment record suggests ice was slightly more extensive than it is today before $\sim 11.2 \mathrm{cal} \mathrm{ka}$ and between $\sim 10.8$ and $\sim 9.8 \mathrm{cal} \mathrm{ka}$. Following emplacement of the Elmendorf Moraine, subsequent recession up the Matanuska valley is constrained by a transect of basal lake sediment ${ }^{14} \mathrm{C}$ ages, which document deglaciation up to the present Matanuska Glacier terminus by 13.7 cal ka (Kopczynski et al., 2017). Greyling Lake, Chugach Mountains, not far downvalley from late Holocene glacier deposits, has a basal ${ }^{14} \mathrm{C}$ age of $15.2 \pm 1.7 \mathrm{cal} \mathrm{ka}$ (McKay and Kaufman, 2009). A pre-Holocene moraine that abuts the lake could be younger than this, but there is no sedimentological record in the lake supporting this interpretation. Four unpublished ${ }^{10} \mathrm{Be}$ ages from the pre-Holocene moraine are scattered (Table 1), ranging in age from 15.4 to $11.0 \mathrm{ka}$. The sampled boulders are a weakly indurated greywacke, and part of a thick blanket of boulders. Given the abundance of boulders from what must have been a very actively eroding headwall, inheritance is unlikely, and the oldest age of $\sim 15.4 \mathrm{ka}$ might be closest to the true moraine age. Although not directly tied to glacier change, a basal ${ }^{14} \mathrm{C}$ age from a lake along the southern coast near Cordova of $\sim 14.6 \mathrm{cal}$ ka reveals deglaciation of the coastline at this time (Garrett et al., 2015). And nearby, Zander et al. (2013) provide lake sediment evidence to indicate glacier extent similar to today from 11.2 to $11.0 \mathrm{ka}$.

To summarize, data available from southern Alaska are mixed about when glaciers retreated to within their late Holocene footprints. Data from most locations suggest this occurred prior to the Younger Dryas, with one site on the Kenai Peninsula and one site near Cordova indicating that ice was near its present extent potentially during the Younger Dryas and even later. The young age $(\sim 13 \mathrm{ka})$ and distal location of glaciotectonized sediments on Kodiak Island is anomalous.

\subsection{Southeast Alaska}

To date, focused research defining the detailed timing of glaciation in Southeast Alaska is in its infancy. However, several efforts thus far have yielded results that have provided some general information on the maximum LGM extent and of the history of subsequent deglaciation. Previous overviews of glaciation in Southeast Alaska discuss how poorly the region's glacial history is understood (Mann, 1986; Mann and Hamilton, 1995). Much of the discussion centered on the timing and extent of LGM ice onto the continental shelf, but was based on little evidence. During the LGM, the Cordilleran glacier complex flowed westward from the crest of the coastal mountains to the coast; Cordilleran ice coalesced with local glaciers from high mountains throughout the Alexander Archipelago (Fig. 1). Parts of the continental shelf were exposed by lower eustatic sea level (Carrara et al., 2007), and much of the evidence for LGM ice extent is now submerged due to postglacial sea level rise. It is thought that some portions of the continental shelf now submerged likely were ice free during the LGM (Carrara et al., 2003, 2007).

Caves in Southeast Alaska contain a varied fauna ( $>50,000$ specimens) ranging in age from $>57,260 \pm 720$ (U-Th age from speleothem that entombs a bone) to the present 
(Heaton and Grady, 2003; Dorale, 2003). Among the $176{ }^{14} \mathrm{C}$-dated specimens are many that lived during the LGM, implying that cave entrances were open and not ice-covered. However, a lack of dated specimens between $\sim 19,500$ and $\sim 17,000$ cal yr BP implies that the western Alexander Archipelago may have been occupied by ice during this time (Heaton and Grady, 2004). Furthermore, recent ${ }^{10} \mathrm{Be}$ ages on erratic boulders and bedrock from small coastal islands west of Prince of Wales Island (Fig. 1) average 16.9 ka (Lesnek et al., 2016). Combined, the cave data and the ${ }^{10} \mathrm{Be}$ ages point to a phase of maximum ice cover between $\sim 19.5$ and $\sim 17 \mathrm{ka}$.

A compilation of ${ }^{14} \mathrm{C}$ ages, largely unpublished, from shells in raised marine deposits throughout Southeast Alaska expands our understanding of the timing of ice retreat (Baichtal, 2010; Carlson and Baichtal, 2015; J. Baichtal unpublished data). In addition to pinpointing the zero-meter isobase and reconstructing relative sea level history in a number of locations, including the history of forebulge migration, the ${ }^{14} \mathrm{C}$ ages reveal the timing of widespread ice retreat through the Alexander Archipelago. It appears that all of Southeast Alaska's major fjords and sounds became ice free sometime between around 13.6 and $14.8 \mathrm{cal} \mathrm{ka}$. The marine reservoir correction is largely unconstrained in this region for samples older than $\sim 11 \mathrm{ka}$; the above age assignment uses a correction of 1100 years (Kovanen and Easterbrook, 2002).

\section{Discussion}

3.1. How did the timing of glacier recession relate to buildup of global $\mathrm{CO}_{2}$, such as during the onset of $\mathrm{CO}_{2}$ rise at $\sim 18 \mathrm{ka}$ ?

We now return to the three questions that we set out to address in the Introduction. The first is how did the timing of glacier recession relate to buildup of global $\mathrm{CO}_{2}$, such as during the onset of $\mathrm{CO}_{2}$ rise at $\sim 18 \mathrm{ka}$ (Marcott et al., 2014)? It is currently debated whether the primary cause of glacier recession during the last deglaciation was greenhouse gas forcing or local factors such as insolation, ice sheet influences or ocean circulation effects. Shakun et al. (2015) suggested that mid-latitude glaciers were largely forced by fluctuations in $\mathrm{CO}_{2}$, but other workers in the Southern Hemisphere pinpoint warming due to the bipolar expression of Heinrich Stadial 1 as an explanation for glacier retreat (e.g., Putnam et al., 2013). In any case, this debate has yet to draw significantly on the alpine glacier record from high northern latitudes such as in Alaska.

It seems that statewide, significant glacier recession took place prior to the global increase in $\mathrm{CO}_{2}$, but much retreat occurred after this. The information available from Southeast Alaska shows a different trend, but this temperate location likely had a different climate regime than the majority of the state. The time-distance diagram from the Brooks Range has room for improvement, because the data come from more than one valley, and we are not confident where to place the recessional moraine dating to $17 \mathrm{ka}$. Nevertheless, based on our best estimate, it appears that the 17 ka moraine is well upvalley from the LGM terminal moraine dating to $21 \mathrm{ka}$ (Fig. 2; Pendleton et al., 2015). In the Ahklun Mountains, the uncertainty in the time-distance diagram revolves around the unknown location of the ice divide that fueled the outlet lobe that flowed down the Goodnews 
River valley. Regardless, the first recessional moraine upvalley from the LGM terminal moraine, which was deposited prior to $\sim 20.4 \mathrm{ka}$, indicates significant glacier recession prior to global $\mathrm{CO}_{2}$ increase (Fig. 2). The McKinley Park sequence also requires some recession prior to $18 \mathrm{ka}$ (Fig. 2). Furthermore, the oldest ${ }^{14} \mathrm{C}$ age on marine sediments at the head of Cook Inlet, near the Elmendorf Moraine, is $\sim 17.6 \mathrm{cal}$ ka (Kopczynski et al., 2017). Based on mapping that shows the occupation of Cook Inlet by ice during the LGM (Kaufman et al., 2011), that the head of Cook Inlet was clear of ice by $17.6 \mathrm{ka}$ implies significant ice recession prior to $18 \mathrm{ka}$.

What drove pre-18 ka glacier retreat in Alaska? Perhaps early glacier recession was due to increasing high northern latitude insolation beginning $23 \mathrm{ka}$ (Berger and Loutre, 1991), which has been hypothesized to have initiated melting of Northern Hemisphere ice sheets (e.g., Alley et al., 2002; Denton et al., 2010; Ullman et al., 2015). Pendleton et al. (2015) suggested that early deglaciation in the Brooks Range may have also been related to the impact that the expanded Laurentide Ice Sheet had on atmospheric circulation. Indeed, simulations by global climate models show that the Laurentide Ice Sheet caused significant warming and drying in the Alaska-Yukon region during the LGM (Roe and Lindzen, 2001; Otto-Bliesner et al., 2006), which agrees with very little LGM temperature depressions based on chironomids (Kurek et al., 2009) and pollen (Bartlein et al., 2011). Regardless, among the eight sites in Alaska reviewed here that have sufficient existing chronology to address this question, data from seven sites support significant glacier recession prior to $\sim 18 \mathrm{ka}$. Based on the glacier histories compiled in Figure 2, glaciers retreated up to $\sim 40 \%$ of their LGM lengths by $\sim 18 \mathrm{ka}$. This amount of retreat is generally greater than the amount of pre-18 ka retreat reported in the compilation of Shakun et al. (2015), suggesting that perhaps insolation forcing has an important effect on high northern latitude glaciers, potentially exacerbated by Arctic amplification.

\subsection{What was the expression of glacier change during Heinrich Stadial 1 (18-15 ka)?}

The second question we aim to address is what was the expression of glacier change during Heinrich Stadial 1 ( 18-14.6 ka; Barker et al., 2009)? There is little doubt that strong cooling in the North Atlantic region related to ocean circulation during Heinrich Stadial 1 affected much of the globe (e.g., Cheng et al., 2009; Barker et al., 2009). It is also a time period of increasing $\mathrm{CO}_{2}$, thus leaving open the possibility for competing cooling and warming climate forcing in some parts of the Northern Hemisphere.

In most locations where recessional moraines have been dated in Alaska, some standstills or re-advances occurred during Heinrich Stadial 1, despite the consistent increase in $\mathrm{CO}_{2}$ between $\sim 18$ and $14.6 \mathrm{ka}$. In the Brooks Range, a prominent recessional moraine is dated to $\sim 17 \mathrm{ka}$, and the Elmendorf Moraine dates to $\sim 16.5 \mathrm{ka}$. On the other hand, given the number of recessional moraines in most valleys, for example throughout the Alaska Range, the Ahklun Mountains, and the Kenai Peninsula, it is difficult to know if these glacial stabilizations necessarily relate to cooling triggered in the North Atlantic Ocean. Rather, they could be related to any number of factors that would cause glacier recession to be interrupted by re-advances or stillstands (e.g., isostatic rebound, solar variability, glacier hypsometric effects). In fact, despite interruptions, there was significant 
recession of glaciers overall through Heinrich Stadial 1 in Alaska. As overviewed above, most paleo-glaciers with secure chronological constraints experienced the majority of their recession during Heinrich Stadial 1.

Clark et al. (2012) suggested that the global pattern of temperature change during the last deglaciation has two expressions: one of increasing temperature that generally mimics atmospheric $\mathrm{CO}_{2}$ concentration, and one more aligned with North Atlantic Ocean forcing. For Beringia, both of these modes are expressed in a compilation of 11 temperature records (Clark et al., 2012), the former being the primary pattern, and the latter being the secondary pattern. In terms of the glacier records presented here, it appears that they too seem mostly influenced by the global pattern of temperature and $\mathrm{CO}_{2}$ rise (Shakun et al., 2012), because they look more like glacial records from around the globe during this interval than climate records from the North Atlantic region.

\subsection{What is the spatio-temporal record of glacier change during the climatically

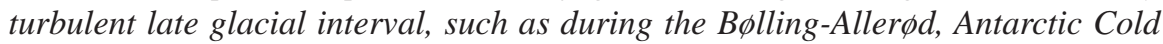 Reversal, and Younger Dryas periods?}

The final goal of this paper is to address the spatio-temporal record of glacier change during the climatically turbulent late glacial interval, such as during the BøllingAllerød, Antarctic Cold Reversal, and Younger Dryas periods. In Southeast Alaska, available evidence suggests widespread glacier collapse throughout fjords and sounds during the Bølling. However, throughout most of Alaska, this question boils down to whether or not there is evidence for glacier re-advances during late glacial times. The existing glacial records reveal very limited evidence for glacier re-advances during the Younger Dryas, and no obvious glacier re-advances during the Antarctic Cold Reversal. The Waskey Mountain moraines in the central Ahklun Mountains are the best evidence to date for glacier response in Alaska during the Younger Dryas, although the chronology is imprecise. Elsewhere, there is evidence for glaciers extending beyond their present footprints during the Younger Dryas in Denali National Park (Muldrow Glacier), in the Kenai Mountains (Emerald Lake) and near Cordova. Out of the 14 glaciers throughout Alaska discussed above, nine retreated upvalley of their late Holocene extent prior to the Younger Dryas period.

In terms of climate conditions in Alaska during the Younger Dryas, a summary by Kokorowski et al. (2008) concluded that evidence for Younger Dryas cooling was mostly absent outside of southern Alaska. Kaufman et al. (2010) also found evidence for Younger Dryas climate change in southern Alaska, notably that the coldest temperature occurred at the beginning of, and was followed by warming throughout, the Younger Dryas. Denton et al. (2005) hypothesized that Younger Dryas cooling was mostly a wintertime phenomenon, and hence may have had limited influence on positive glacier mass balance. This is supported in Arctic Alaska with the documentation of extreme winter temperature depression during the Younger Dryas (Meyer et al., 2010), whereas most pollen records summarized by Kokorowski et al. (2008) show no significant cooling. Adding to the hemispheric climate forcing transmitted from the North Atlantic region was the time-transgressive flooding of Bering Strait around the time of the 
Younger Dryas (England and Furze, 2008), although the land bridge may not have been completed severed until around $11 \mathrm{ka}$ (Jakobsson et al., 2017). This flooding event may have led to regional forcing, such as an increase in precipitation due to more northerly storm tracks (Kaufman et al., 2010) that may have influenced glacier mass balance. Of course, there could have been more glacier fluctuations during the Younger Dryas than are currently recognized because they may have occurred during a climate state that was warmer than the late Holocene (e.g., Kurek et al., 2009; Kaufman et al., 2016), and hence moraines were later obscured by subsequent glacier advances during the Holocene.

\section{Conclusion}

In this brief overview of the deglaciation of Alaska, we sought to address three questions about the last glacial termination. Despite there being a lack of complete, well-dated and precise glacial chronologies from single valleys, the existing record is nonetheless useful. There is overwhelming evidence that glaciers throughout Alaska experienced significant retreat prior to the global increase in atmospheric $\mathrm{CO}_{2}$ at $\sim 18$ ka. The exact amount is difficult to quantify, but glaciers at seven out of the eight sites summarized here experienced significant recession prior to $\sim 18 \mathrm{ka}$. Data from the three time-distance diagrams compiled here suggest that glaciers retreated about $40 \%$ of their LGM lengths. Despite multiple recessional moraines in most valleys that date to within Heinrich Stadial 1, overall glacier recession during this interval is more consistent with global forcing than with the influence of North Atlantic Ocean circulation changes. Finally, nine out of 14 records throughout the state that relate to glacier re-advance during the Younger Dryas suggest that a re-advance, if any, must have been restricted to within late Holocene glacier extents. Most of the sites with evidence for relatively extensive glaciers during the Younger Dryas are in southern Alaska. More firm answers to the questions we set out to address must await additional well-constrained glacial chronologies from multiple locations within single valleys. The chronological tools are available, and the geomorphological record of glacier change during the last glaciation is spectacular across much of the state. Together they warrant continued, focused efforts in well-chosen locations.

\section{References}

Alley, R.B., Brook, E.J., Anandakrishnan, S. 2002. A northern lead in the orbital band: north-south phasing of Ice-Age events. Quaternary Science Reviews EPILOG 21, 431-441. http://doi. org/10.1016/S0277-3791(01)00072-5.

Ager, T.A., Sims, J.D. 1981. Holocene pollen and sediment record from the tangle lakes area, central Alaska. Palynology 5, 85-98. http://doi.org/10.1080/01916122.1981.9989220.

Badding, M.E., Briner, J.P., Kaufman, D.S. 2013. ${ }^{10}$ Be ages of late Pleistocene deglaciation and Neoglaciation in the north-central Brooks Range, Arctic Alaska. Journal of Quaternary Science 28, 95-102. http://doi.org/10.1002/jqs.2596.

Baichtal, J.F. 2010. Development of a paleoshoreline model to predict the location of early holocene habitation sites on Prince of Wales Island and the adjacent Outer Islands, Southeast Alaska. Abstracts with programs - Geological Society of America 42 (5), p. 349. 
Balascio, N.L., Kaufman, D.S., Briner, J.P., Manley, W.F. 2005. Late Pleistocene Glacial Geology of the Okpilak-Kongakut Rivers Region, Northeastern Brooks Range, Alaska. Arctic, Antarctic, and Alpine Research 37, 416-424.

Balco, G. 2011. Contributions and unrealized potential contributions of cosmogenic-nuclide exposure dating to glacier chronology, 1990-2010. Quaternary Science Reviews 30, 3-27. http://doi.org/10.1016/j.quascirev.2010.11.003.

Balco, G., Stone, J.O., Lifton, N.A., Dunai, T.J. 2008. A complete and easily accessible means of calculating surface exposure ages or erosion rates from $10 \mathrm{Be}$ and $26 \mathrm{Al}$ measurements. Quaternary Geochronology, Prospects for the New Frontiers of earth and Environmental Sciences 3, 174-195. http://doi.org/10.1016/j.quageo.2007.12.001.

Barclay, D.J., Wiles, G.C., Calkin, P.E. 2009. Holocene glacier fluctuations in Alaska. Quaternary Science Reviews 28, 2034-2048. http://doi.org/10.1016/j.quascirev.2009.01.016.

Barker, S., Diz, P., Vautravers, M.J., Pike, J., Knorr, G., Hall, I.R., Broecker, W.S. 2009. Interhemispheric Atlantic seesaw response during the last deglaciation. Nature 457, 10971102. http://doi.org/10.1038/nature07770.

Bartlein, P.J., Harrison, S.P., Brewer, S., Connor, S., Davis, B. a. S., Gajewski, K., Guiot, J., Harrison-Prentice, T.I., Henderson, A., Peyron, O., Prentice, I.C., Scholze, M., Seppä, H., Shuman, B., Sugita, S., Thompson, R.S., Viau, A.E., Williams, J., Wu, H. 2011. Pollen-based continental climate reconstructions at 6 and 21 ka: a global synthesis. Climate Dynamics 37, 775-802. http://doi.org/10.1007/s00382-010-0904-1.

Berger, A., Loutre, M.F. 1991. Insolation values for the climate of the last 10 million years. Quaternary Science Reviews 10, 297-317. http://doi.org/10.1016/0277-3791(91)90033-Q.

Briner, J.P., Kaufman, D.S. 2008. Late Pleistocene mountain glaciation in Alaska: key chronologies. Journal of Quaternary Science 23, 659-670. http://doi.org/10.1002/jqs.1196.

Briner, J.P., Kaufman, D.S., Manley, W.F., Finkel, R.C., Caffee, M.W. 2005. Cosmogenic exposure dating of late Pleistocene moraine stabilization in Alaska. Geological Society of America Bulletin 117, 1108-1120.

Briner, J.P., Kaufman, D.S., Werner, A., Caffee, M., Levy, L., Manley, W.F., Kaplan, M.R., Finkel, R.C. 2002. Glacier readvance during the late glacial (Younger Dryas?) in the Ahklun Mountains, southwestern Alaska. Geology 30, 679-682. http://doi.org/10.1130/00917613(2002)030<0679:GRDTLG > 2.0.CO;2.

Carrara, P.E., Ager, T.A., Baichtal, J.F., VanSistine, D.P. 2003. Map of glacial limits and possible refugia in the southern Alexander Archipelago, Alaska, during the late Wisconsin glaciation. U.S. Geological Survey Miscellaneous Field Studies Map MF-2424, U.S. Geological Survey, Denver, Colorado.

Carrara, P.E., Ager, T.A., Baichtal, J.F. 2007. Possible refugia in the Alexander Archipelago of southeastern Alaska during the late Wisconsin glaciation. Canadian Journal of Earth Sciences 44 (2), 229-244. http://doi.org/10.1139/e06-081.

Carlson, R.J., Baichtal, J.F. 2015. A predictive model for locating early Holocene archaeological sites based on raised Shell-Bearing strata in Southeast Alaska, USA. Geoarchaeology 30 (2), 120-138. http://doi.org/10.1002/gea.21501.

Cheng, H., Edwards, R.L., Broecker, W.S., Denton, G.H., Kong, X., Wang, Y., Zhang, R., Wang, X. 2009. Ice Age Terminations. Science 326, 248-252. http://doi.org/10.1126/science.1177840.

Child J.C. 1995. A late Wisconsinan lacustrine record of environmental change in the Wonder Lake area, Denali National Park and Preserve, AK. MS thesis, University of Massachusetts, $205 \mathrm{pp}$.

Clark, P.U., Shakun, J.D., Baker, P.A., Bartlein, P.J., Brewer, S., Brook, E., Carlson, A.E., Cheng, H., Kaufman, D.S., Liu, Z., Marchitto, T.M., Mix, A.C., Morrill, C., Otto-Bliesner, B.L., Pahnke, K., Russell, J.M., Whitlock, C., Adkins, J.F., Blois, J.L., Clark, J., Colman, S.M., Curry, W.B., Flower, B.P., He, F., Johnson, T.C., Lynch-Stieglitz, J., Markgraf, V., McManus, 
J., Mitrovika, J.X., Moreno, P.I., William, J.W. 2012. Global climate evolution during the last deglaciation. PNAS 109, E1134-E1142. http://doi.org/10.1073/pnas.1116619109.

Denton, G.H., Alley, R.B., Comer, G.C., Broecker, W.S. 2005. The role of seasonality in abrupt climate change. Quaternary Science Reviews 24, 1159-1182. http://doi.org/10.1016/j. quascirev.2004.12.002.

Denton, G.H., Anderson, R.F., Toggweiler, J.R., Edwards, R.L., Schaefer, J.M., Putnam, A.E. 2010. The Last Glacial Termination. Science 328, 1652-1656. http://doi.org/10.1126/science.1184119.

Dorale, J.A., Heaton, T.H., Edwards, R.L. 2003. U-Th dating of fossil-associated cave calcites from Southeastern Alaska. Abstracts with Programs - Geological Society of America 35 (6), September 2003, p. 334.

Dortch, J.M., Owen, L.A., Caffee, M.W., Brease, P. 2010a. Late Quaternary glaciation and equilibrium line altitude variations of the McKinley River region, central Alaska Range. Boreas 39, 233-246. http://doi.org/10.1111/j.1502-3885.2009.00121.x.

Dortch, J.M., Owen, L.A., Caffee, M.W., Li, D., Lowell, T.V. 2010b. Beryllium-10 surface exposure dating of glacial successions in the Central Alaska Range. Journal of Quaternary Science 25, 1259-1269. http://doi.org/10.1002/jqs.1406.

Dyke, A.S., Moore, A., Robertson, L. 2003. Deglaciation of North America. Geological Survey of Canada, Open File 1574.

England, J.H., Furze, M.F.A. 2008. New evidence from the western Canadian Arctic Archipelago for the resubmergence of Bering Strait. Quaternary Research 70, 60-67. http://doi. org/10.1016/j.yqres.2008.03.001.

Garrett, E., Barlow, N.L.M., Cool, H., Kaufman, D.S., Shennan, I., Zander, P.D. 2015. Constraints on regional drivers of relative sea-level change around Cordova, Alaska. Quaternary Science Reviews 113, 48-59. http://doi.org/10.1016/j.quascirev.2014.12.002.

Hamilton, T.D. 1986. Late Cenozoic Glaciation of the Central Brooks Range. In: T.D. Hamilton, K.M. Reed, R.M. Thorson (Eds). Alaska Geological Society, Anchorage pp. 9-50.

Hamilton, T.D. 1994. Late Cenozoic glaciation of Alaska: the geology of Alaska. In: G. Plafker, H.C. Berg (Eds.), The Geology of North America. Geological Society of America, Boulder, CO, pp. 813-844.

Hamilton, T.D. 2003. Surficial geology of the Dalton Highway (Itkillik-Sagavanirktok Rivers) area, southern Arctic Foothills. Professional Report, 121. Alaska Department of Natural Resources/Division Geological and Geophysical Surveys.

Heaton, T.H., Grady, F. 2003. The Late Wisconsin vertebrate history of Prince of Wales Island, Southeast Alaska. In: B.W. Schubert, J.I. Mead, R.W. Graham (Eds.), Ice Age Cave Faunas of North America. Indiana University Press, pp. 17-53.

Heaton, T.H., Grady, F. 2004. Detailed vertebrate history of Southeast Alaska during the Last Glacial Maximum. Journal of Vertebrate Paleontology 24 (3), 69A.

Heyman, J., Stroeven, A.P., Harbor, J.M., Caffee, M.W. 2011. Too young or too old: Evaluating cosmogenic exposure dating based on an analysis of compiled boulder exposure ages. Earth and Planetary Science Letters 302, 71-80. http://doi.org/10.1016/j.eps1.2010.11.040.

Howley, M.W. 2008. A late glacial and Holocene chronology of the Castner Glacier, Delta River valley, Alaska. M.S. Thesis, University of New Hampshire, 88 pp.

Jakobsson, M., Pearce, C., Cronin, T.M., Backman, J., Anderson, L.G., Barrientos, N., Björk, R.G., Coxall, H., de Boer, A., Mayer, L.A., Mörth, C.-M., Nilsson, J., Rattray, J.E., Stranne, C., Semilietov, I., O'Regan, M. 2017. Post-glacial flooding of the Beringia Land Bridge dated to $11,000 \mathrm{cal}$ yrs BP based on new geophysical and sediment records. Climate of the Past Discussions. http://doi.org/10.5194/cp-2017-11.

Kaufman, D.S., Hu, F.S., Briner, J.P., Werner, A., Finney, B.P., Gregory-Eaves, I. 2003. A -33,000 year record of environmental change from Arolik Lake, Ahklun Mountains, Alaska, USA. Journal of Paleolimnology 30, 343-361. http://doi.org/10.1023/B:JOPL.0000007219.15604.27. 
Kaufman, D.S., Anderson, R.S, Hu, F.S., Berg, E., Werner, A. 2010. Evidence for a variable and wet Younger Dryas in southern Alaska. Quaternary Science Reviews 29, 1445-1452. http:// doi.org/10.1016/j.quascirev.2010.02.025.

Kaufman, D.S., Young, N.E., Briner, J.P., Manley, W.F. 2011. Alaska Palaeo-Glacier Atlas (Version 2). In: Developments in Quaternary Sciences. Elsevier, pp. 427-445.

Kaufman, D.S., Jensen, B.J.L., Reyes, A.V., Schiff, C.J., Froese, D.G., Pearce, N.J.G. 2012. Late Quaternary tephrostratigraphy, Ahklun Mountains, SW Alaska. Journal of Quaternary Science 27, 344-359. http://doi.org/10.1002/jqs.1552.

Kaufman, D.S., Axford, Y.L., Henderson, A.C.G., McKay, N.P., Oswald, W.W., Saenger, C., Anderson, R.S., Bailey, H.L., Clegg, B., Gajewski, K., Hu, F.S., Jones, M.C., Massa, C., Routson, C.C., Werner, A., Wooller, M.J., Yu, Z. 2016. Holocene climate changes in eastern Beringia (NW North America) - A systematic review of multi-proxy evidence. Quaternary Science Reviews 147, 312-339. http://doi.org/10.1016/j.quascirev.2015.10.021.

Kokorowski, H.D., Anderson, P.M., Mock, C.J., Lozhkin, A.V. 2008. A re-evaluation and spatial analysis of evidence for a Younger Dryas climatic reversal in Beringia. Quaternary Science Reviews 27, 1710-1722. http://doi.org/10.1016/j.quascirev.2008.06.010.

Kopczynski, S.E., Kelley, S.E., Lowell, T.V., Evenson, E.B., Applegate, P.J. 2017. Latest Pleistocene advance and collapse of the Matanuska-Knikglacier system,AnchorageLowland, southernAlaska. Quaternary Science Reviews 156, 121-134. http://doi.org/10.1016/j.quascirev.2016.11.026.

Kovanen, D.J., Easterbrook, D.J. 2002. Paleodeviations of radiocarbon marine reservoir values for the northeast Pacific. Geology 30 (3), 243-246. http://doi.org/10.1130/00917613(2002)030<0243:PORMRV>2.0.CO;2.

Kurek,J.,Cwynar,L.C.,Ager, T.A.,Abbott, M.B.,Edwards, M.E. 2009. Late Quaternary paleoclimate of western Alaska inferred from fossil chironomids and its relation to vegetation histories. Quaternary Science Reviews 28, 799-811. http://doi.org/10.1016/j.quascirev.2008.12.001.

LaBrecque, T.S., Kaufman, D.S. 2016. Holocene glacier fluctuations inferred from lacustrine sediment, Emerald Lake, Kenai Peninsula, Alaska. Quaternary Research 85, 34-43. http:// doi.org/10.1016/j.yqres.2015.11.004.

Laskar, J., Robutel, P., Joutel, F., Gastineau, M., Correia, A.C.M., Levrard, B. 2004. A long-term numerical solution for the insolation quantities of the Earth. Astronomy \& Astrophysics 428, 261-285. http://doi.org/10.1051/0004-6361:20041335.

Lesnek, J.L., Briner, J.P. 2016. It takes two: New constraints on Cordilleran Ice Sheet extent and retreat from ${ }^{10} \mathrm{Be}$ and radiocarbon dating. American Geophysical Union annual meeting, San Francisco, California, USA, December 12-16.

Levy, L.B., Kaufman, D.S., Werner, A. 2004. Holocene glacier fluctuations, Waskey Lake, northeastern Ahklun Mountains, southwestern Alaska. The Holocene 14, 185-193. http://doi. org/10.1191/0959683604hl675rp.

Manley, W.F., Kaufman, D.S., Briner, J.P. 2001. Pleistocene glacial history of the southern Ahklun Mountains, southwestern Alaska: Soil-development, morphometric, and radiocarbon constraints. Quaternary Science Reviews 20, 353-370. http://doi.org/10.1016/S0277-3791(00)00111-6.

Mann, D.H. 1986. Wisconsin and Holocene Glaciation of Southeast Alaska. In: T.D. Hamilton, K.M. Reed, R.M. Thorson (Eds.), Glaciation in Alaska: The geologic record. Alaska Geological Society, Anchorage, pp. 237-261.

Mann, D.H., Peteet, D.M. 1994. Extent and Timing of the Last Glacial Maximum in Southwestern Alaska. Quaternary Research 42, 136-148. http://doi.org/10.1006/qres.1994.1063.

Mann, D.H., Hamilton, T.D. 1995. Late Pleistocene and Holocene paleoenvironments of the North Pacific Coast. Quaternary Science Reviews 14, 449-471. https://doi.org/10.1016/02773791(95)00016-I.

Marcott, S.A., Bauska, T.K., Buizert, C., Steig, E.J., Rosen, J.L., Cuffey, K.M., Fudge, T.J., Severinghaus, J.P., Ahn, J., Kalk, M.L., McConnell, J.R., Sowers, T., Taylor, K.C., White, 
J.W.C., Brook, E.J. 2014. Centennial-scale changes in the global carbon cycle during the last deglaciation. Nature 514, 616-619. http://doi.org/10.1038/nature13799.

Matmon, A., Schwartz, D.P., Haeussler, P.J., Finkel, R., Lienkaemper, J.J., Stenner, H.D., Dawson, T. 2006. Denali fault slip rates and Holocene-late Pleistocene kinematics of central Alaska. Geology 34, 645-648. http://doi.org/10.1130/G22361.1.

Matmon, A., Briner, J.P., Carver, G., Bierman, P., Finkel, R.C. 2010. Moraine chronosequence of the Donnelly Dome region, Alaska. Quaternary Research 74, 63-72. http://doi.org/10.1016/j. yqres.2010.04.007.

McKay, N.P., Kaufman, D.S. 2009. Holocene climate and glacier variability at Hallet and Greyling Lakes, Chugach Mountains, south-central Alaska. Journal of Paleolimnolology 41, 143-159. http://doi.org/10.1007/s10933-008-9260-0.

Meyer, H., Schirrmeister, L., Yoshikawa, K., Opel, T., Wetterich, S., Hubberten, H.-W., Brown, J. 2010. Permafrost evidence for severe winter cooling during the Younger Dryas in northern Alaska. Geophysical Research Letters 37, L03501. http://doi.org/10.1029/2009GL041013.

Otto-Bliesner, B.L., Brady, E.C., Clauzet, G., Tomas, R., Levis, S., Kothavala, Z. 2006. Last Glacial Maximum and Holocene Climate in CCSM3. Journal of Climate 19 (11), 2526-2544. http://doi.org/10.1175/JCLI3748.1.

Pendleton, S.L., Ceperley, E.G., Briner, J.P., Kaufman, D.S., Zimmerman, S. 2015. Rapid and early deglaciation in the central Brooks Range, Arctic Alaska. Geology 43, 419-422. http:// doi.org/10.1130/G36430.1.

Porter SC, Pierce KL, Hamilton TD. 1983. Late Wisconsin mountain glaciation in the western United States. In Late Quaternary Environments of the United States. In: S.C. Porter (Ed.), The Late Pleistocene, Vol. 1. University of Minnesota Press, Minneapolis, pp. 71-111.

Putnam, A.E., Denton, G.H., Schaefer, J.M., Barrell, D.J.A., Andersen, B.G., Finkel, R.C., Schwartz, R., Doughty, A.M., Kaplan, M.R., Schlüchter, C. 2010. Glacier advance in southern middle-latitudes during the Antarctic Cold Reversal. Nature Geoscience 3, 700704. http://doi.org/10.1038/ngeo962.

Putnam, A.E., Schaefer, J.M., Denton, G.H., Barrell, D.J.A., Andersen, B.G., Koffman, T.N.B., Rowan, A.V., Finkel, R.C., Rood, D.H., Schwartz, R., Vandergoes, M.J., Plummer, M.A., Brocklehurst, S.H., Kelley, S.E., Ladig, K.L. 2013. Warming and glacier recession in the Rakaia valley, Southern Alps of New Zealand, during Heinrich Stadial 1. Earth and Planetary Science Letters 382, 98-110. http://doi.org/10.1016/j.eps1.2013.09.005.

Reger, R.D., Stevens, D.S.P., and Solie, D.N. 2008a. Surficial-geologic map, Alaska Highway corridor, Delta Junction to Dot Lake, Alaska. State of Alaska Department of Natural Resources Division of Geological \& Geophysical Surveys, 54 pp.

Reger, R.D., Sturmann, A.G., Berg, E.E., Burns, P.A.C. 2008b. A Guide to the Late Quaternary History of Northern and Western Kenai Peninsula, Alaska. State of Alaska Department of Natural Resources Division of Geological \& Geophysical Surveys, 112 pp.

Roe, G.H., Lindzen, R.S. 2001. A one-dimensional model for the interaction between continentalscale ice sheets and atmospheric stationary waves. Climate Dynamics 17, 479-487. http://doi. org/10.1007/s003820000123.

Roe, G.H., Baker, M.B., Herla, F. 2017. Centennial glacier retreat as categorical evidence of regional climate change. Nature Geoscience 10, 95-99. http://doi.org/10.1038/ngeo2863.

Shakun, J.D., Clark, P.U., He, F., Marcott, S.A., Mix, A.C., Liu, Z., Otto-Bliesner, B., Schmittner, A., Bard, E. 2012. Global warming preceded by increasing carbon dioxide concentrations during the last deglaciation. Nature 484, 49-54. http://doi.org/10.1038/nature10915.

Shakun, J.D., Clark, P.U., He, F., Lifton, N.A., Liu, Z., Otto-Bliesner, B.L. 2015. Regional and global forcing of glacier retreat during the last deglaciation. Nature Communications 6, 8059 . http://doi.org/10.1038/ncomms9059.

Stuiver, M., Reimer, P.J., Reimer, R.W. 2017, CALIB 7.1 [WWW program] at http://calib.org. 
Ten Brink, N.W., Waythomas, C.F. 1985. Late Wisconsin glacial chronology of the north-central Alaska Range: a regional synthesis and its implications for early human settlements. In: W.R. Powers et al. (Eds.), North Alaska Range Early Man Project. National Geographic Society Research Reports, National: Geographic Society Washington, DC, pp. 15-32.

Ullman, D.J., Carlson, A.E., LeGrande, A.N., Anslow, F.S., Moore, A.K., Caffee, M., Syverson, K.M., Licciardi, J.M. 2015.Southern Laurentide ice-sheet retreat synchronous with rising boreal summer insolation. Geology 43, 23-26. http://doi.org/10.1130/G36179.1.

Werner, A., Wright, K, Child, J. 1993. Bluff stratigraphy along the McKinley River: a record of late Wisconsin climatic change. Abstracts with Programs - Geological Society of America $25,224$.

Young, N.E., Briner, J.P., Kaufman, D.S. 2009. Late Pleistocene and Holocene glaciation of the Fish Lake valley, northeastern Alaska Range, Alaska. Journal of Quaternary Science 24, 677-689. http://doi.org/10.1002/jqs.1279.

Young, N.E., Schaefer, J.M., Briner, J.P., Goehring, B.M. 2013. A 10Be production-rate calibration for the Arctic. Journal of Quaternary Science 28, 515-526. http://doi.org/10.1002/jqs.2642.

Zander, P.D., Kaufman, D.S., Kuehn, S.C., Wallace, K.L., Anderson, R.S. 2013. Early and late Holocene glacial fluctuations and tephrostratigraphy, Cabin Lake, Alaska. Journal of Quaternary Science 28, 761-771. http://doi.org/10.1002/jqs.2671.

See supplementary material at:

http://publicaciones.unirioja.es/revistas/cig2017/briner_supplmat.kml 